\title{
PENGARUH TINGKAT PENDIDIKAN KARYAWAN \\ TERHADAP PENJUALAN PUPUK \\ PADA CV. PANDAN WANGI KAB. MADIUN
}

\author{
Nia Tri Handayani \\ Mahasiswi Prodi Pendidikan Ekonomi IKIP PGRI Madiun
}

\begin{abstract}
Abstrak: Penelitian ini bertujuan untuk mengetahui Tingkat Pendidikan Karyawan pada CV. Pandan Wangi, untuk mengetahui Penjualan Pupuk pada CV. Pandan Wangi, dan untuk mengetahui adakah pengaruh tingkat pendidikan karyawan terhadap penjualan pupuk pada CV. Pandan Wangi Kab Madiun. Penentuan sampel di dalam penelitian ini menggunakan sampel jenuh yaitu karyawan dan populasi sebanyak 40 orang. Pengumpulan data menggunakan metode dokumentasi digunakan untuk mengambil data tingkat pendidikan karyawan, data penjualan pupuk dan metode wawancara digunakan untuk mengambil data tingkat pendidikan karyawan, penjualan pupuk. Dalam menganalisis data digunakan metode statistik dengan rumus uji $\mathrm{r}$, uji $\mathrm{F}$, uji t. Hasil penelitian menunjukkan bahwa tingkat pendidikan karyawan mempunyai pengaruh sekaligus hubungan yang positif terhadap penjualan pupuk pada CV. Pandan Wangi Kab. Madiun. Hal ini diperoleh dari $r_{\text {hitung }}$ sebesar 0,732 sedangkan $r_{\text {tabel }} 0,312$ yang artinya $r_{\text {hitung }}>r_{\text {tabel }}(0,732>0,312)$ yang menyatakan adanya penolakan Ho artinya tingkat pendidikan karyawan mempunyai hubungan dengan penjualan pupuk. Selain itu juga diperoleh koefisien regresi (uji $t$ ) dengan nilai dari $t_{\text {hitung }}$ sebesar 6,632 $\geq t_{\text {tabel }}$ pada signifikansi 0,05 dengan uji dua pihak dan jumlah data dalam penelitian 5. Maka diperoleh $t_{\text {tabel }}$ sebesar 1,745. Hal ini berarti nilai $t_{\text {hitung }}>t_{\text {tabel }}(6,632>$ 1.745) maka tolak Ho yang artinya bahwa ada pengaruh tingkat pendidikan karyawan terhadap penjualan pupuk pada CV. Pandan Wangi Kab. Madiun. Jadi kesimpulannya ada Pengaruh Tingkat Pendidikan Karyawan Terhadap Penjualan Pupuk pada CV. Pandan Wangi Kab. Madiun. Saran untuk penelitian ini ke depannya diharapkan karyawan dapat meningkatkan tingkat pendidikan ke jenjang yang lebih tinggi.
\end{abstract}

Kata Kunci: Tingkat Pendidikan Karyawan, Penjualan Pupuk

\section{PENDAHULUAN}

Intensitas kebutuhan manusia mengalami perubahan seiring dengan perkembangan zaman. Berbagai macam sektor dalam bidang ekonomi terus berusaha untuk mencukupi kebutuhan tersebut dengan melakukan berbagai macam pembaharuan. Dengan adanya pembaharuan diharapakan akan menarik keinginan konsumen dalam membeli suatu produk yang ditawarkan.

Persekutuan Komanditer atau CV adalah suatu persekutuan yang didirikan oleh seorang atau beberapa orang yang mempercayakan uang atau barang kepada seorang atau beberapa orang yang menjalankan perusahaan dan bertindak sebagai pemimpin.

Menurut Bambang Prishardoyo (2005: 105) menyatakan bahwa Persekutuan Komanditer (CV) didirikan oleh beberapa orang sebagaimana mendirikan firma. Didirikan dihadapan notaris untuk dibuatkan akte pendiriannya. Apabila pendirinya yang sekaligus sebagai pemilik ingin memperbesar modal perusahaan dan tidak menghendaki kepemimpinannya dicampuri oleh orang lain, maka akan diterbitkan surat-surat sero atau saham yang kemudian dijual kepada masyarakat yang membutuhkan. 
Jiwa kepemimpinan dalam persekutuan komanditer merupakan tokoh sentral yang harus dimiliki seorang direktur. Mengingat dalam pendirian usaha ada pihak pasif dan pihak yang aktif. Dimana pihak aktif selaku pengelola $\mathrm{CV}$ secara menyeluruh atas berjalannya usaha, sekaligus memberikan laporan administrasi dan finansial kepada pihak pasif selaku penanam modal.

Dalam perkembangan dunia bisnis baik itu perusahaan-perusahaan industri ataupun industri rumah tangga (home industri) berkembang semakin pesat dan ketat. Adanya persaingan pada usaha yang homogen ini, pengelola persekutuan komanditer diharapkan mampu menjaga amanah dan mengambil keputusan yang tepat, agar usaha yang dijalankan berkembang sesuai dengan tujuan bersama.

CV. Pandan Wangi dalam usahanya memproduksi Urea, Za, Npk, SP3, Phonska, dan petroganik. Pada prakteknya CV. Pandan Wangi hanya memproduksi petroganik saja karena hasil produksi yang lain merupakan hasil dari suply Pupuk Kaltim.

CV. Pandan Wangi merupakan persekutuan komanditer yang bergerak dalam bidang usaha pertanian. Perusahaan ini menyalurkan berbagai macam pupuk sekaligus langsung menjualnya kepada petani. Adanya tujuan yang mendasari berdirinya CV. Pandan Wangi adalah mempermudah petani untuk mencari pupuk guna menangani gulma tanaman, sehingga akan mendapat hasil yang lebih melimpah.

Seiring dengan kebutuhan pupuk yang semakin meningkat maka kegiatan CV. Pandan Wangi memberikan berbagai macam alternatif dalam penanggulangan hama dengan produk yang dimiliki. CV. Pandan Wangi merupakan suatu wadah dimana orientasinya adalah pemenuhan kebutuhan petani dalam penanggulangan hama.

Pupuk yang dihasilkan CV. Pandan Wangi berfungsi untuk menggemburkan dan menyuburkan tanah, meningkatkan daya simpan dan daya serap air, memperkaya unsur hara dalam tanah secara makro dan mikro, sesuai untuk semua jenis tanah dan jenis tanaman, keunggulan kadar C-organik tinggi, berbentuk granule sehingga mudah dalam aplikasi aman dan ramah lingkungan. Bebas mikroba patogen, bebas dari biji-bijian gulma, kadar air rendah sehingga lebih efisien dalam pengangkutan dan penyimpanan dikemas dalam kantong kedap.

Penggunaan Pupuk Petroganik seluruhnya pada pemupukan dasar, sedangkan untuk tanaman keras diberikan pada awal dan akhir musim hujan, sehingga dengan adanya hasil produksi dari pupuk ini dapat membantu petani dalam mengentaskan masalah dari munculnya gulma sekaligus mengembalikan unsur hara dalam tanah.

Setiap persekutuan komanditer mempunyai tujuan-tujuan yang harus dicapai. Dalam usahanya yang berkaitan dengan pasar, tentu dipengaruhi dengan adanya penjualan. Pada periode tertentu diharapkan persekutuan komanditer mempunyai hasil penjualan yang dicapai.

Penjualan pada CV. Pandan Wangi ditentukan dari adanya kinerja dan efektivitas karyawan. Apabila karyawan mampu memberikan pelatihan dan pemahaman yang bagus tanpa memunculkan spekulasi ganda pada petani maka akan meningkatkan hasil penjualan.

Tenaga kerja atau karyawan merupakan faktor produksi yang bersifat senantiasa bergerak dan selalu berubah-ubah, mempunyai akal dan perasaan serta motivasi, jika tenaga kerja sebagai faktor produksi merasa senang bekerja dengan penuh semangat dan bergairah, maka dapat dipastikan bahwa tujuan yang telah ditetapkan perusahaan atau organisasi akan semakin mudah tercapai.

Persaingan usaha yang dapat digolongkan homogen membutuhkan kemampuan soft skill dan hard skil yang di atas rata-rata. Maka dibutuhkan sebuah tingkat pendidikan yang lebih tinggi sesuai keahliannya, yang lebih 
mampu bersaing untuk memasuki dunia kerja dengan lebih baik. Dengan bertambahnya tingkat pendidikan seorang karyawan dalam dunia kerja, maka akan bertambah pula pengetahuan, ketrampilan, kecakapan dan kecekatan dalam pengabdian kerjanya di perusahaan.

Apabila perusahaan menginginkan untuk membentuk seorang karyawan agar perusahaan semakin mengikuti perkembangan zaman dan dapat meningkatkan hasil penjualannya, maka yang dibutuhkan adalah tingkat pendidikan karyawan yang dibutuhkan oleh perusahaan. Dalam pendidikan terdapat proses yang terus menerus berjalan dan bukan sesaat saja. Namun pendidikan juga bisa disebut sebagai usaha untuk meningkatkan pengetahuan umum seseorang termasuk di dalamnya penguasaan teori untuk memutuskan persoalan-persoalan yang menyangkut kegiatan pencapaian tujuan perusahaan.

Dalam hal ini yang dibahas secara spesifik adalah mengenai pendidikan para karyawan yang berijazah akhir Sekolah Menengah Pertama (SMP), Sekolah Menengah Atas (SMA) dan Penguruan Tinggi (D3 atau S1). Hal ini dikarenakan pendidikan tersebut berada dalam lingkungan kerja CV. Pandan Wangi. Banyak di antara karyawan tersebut memiliki masa bekerja yang sudah sedemikian lama, umumnya di atas lima tahun mereka bertahan. Ironisnya karyawan yang senior tersebut hanya memiliki tingkat pendidikan SMP dan SMA, sedangkan yang lulusan perguruan tinggi jumlahnya sedikit sekali. Jikalau hal ini tetap dipertahankan maka kelak, mereka akan memiliki kompetitor-kompetitor dari berbagai sub bidang ilmu yang akan membuat mereka tertinggal jauh di belakang. Seperti yang telah kita ketahui bersama, dari waktu ke waktu zaman semakin berubah. Perusahaan juga dituntut agar penjualan produknya semakin meningkat di tengah persaingan yang sangat ketat seperti sekarang ini.

\section{Kajian Pustaka dan Hipotesis Penelitian}

\section{Kajian Pustaka}

\section{Penjualan}

a. Pengertian Penjualan

Aktivitas penjualan merupakan pendapatan utama perusahaan karena jika aktivitas penjualan produk maupun jasa tidak dikelola dengan baik maka secara langsung dapat merugikan perusahaan. Hal ini dapat disebabkan karena sasaran penjualan yang diharapkan tidak tercapai dan pendapatan pun akan berkurang.

Untuk lebih jelasnya dapat dilihat dari pengertian penjualan itu sendiri adalah sebagai berikut:

Pengertian penjualan menurut Robert Aston (2005:8) Penjualan adalah proses saat seseorang membantu orang lain mengambil keputusan pembelian. Menurut Basu Swastha (2009: 8) Menjual adalah ilmu dan seni mempengaruhi pribadi yang dilakukan oleh penjual untuk mengajak orang lain agar bersedia membeli barang/ jasa yang ditawarkannya.

Berdasarkan pengertian di atas, maka dapat disimpulkan bahwa penjualan adalah persetujuan kedua belah pihak antara penjual dan pembeli, dimana penjual menawarkan suatu produk dengan harapan pembeli dapat menyerahkan sejumlah uang sebagai alat ukur produk tersebut sebesar harga jual yang telah disepakati.

Basu Swastha (2002:183) Penjualan merupakan fungsi yang paling penting dalam pemasaran karena menjadi tulang punggung kegiatan untuk mencapai pasar yang dituju. Fungsi penjualan juga merupakan sumber pendapatan yang diperlukan untuk menutup ongkos-ongkos dengan harapan bisa mendapatkan laba.

Himayati (2008:123) Penjualan adalah suatu transaksi yang bertujuan untuk mendapatkan suatu keuntungan, dan merupakan suatu jantung dari suatu perusahaan. Penjualan bisa dilakukan 
dengan jasa atau barang, baik kredit maupun cash.

Manfaat dari penjualan di atas jelas memberi arahan bahwa, penjualan tidak dapat dipisahkan dari adanya proses produksi suatu usaha. Dimana keuntungan dari penjualan dapat menutupi besar biaya produksi.

b. Jenis-jenis Penjualan

Ada beberapa macam jenis penjualan bahwa menurut Basu Swastha dapat diklasifikasikan (2009:11-12) sebagai berikut:

\section{1) Trade Selling}

Trade Selling dapat terjadi bila mana produsen dan pedagang besar mempersilahkan pengecer untuk berusaha memperbaiki distributor produkproduk mereka.

2) Missionary Selling

Missionary Selling penjualan berusaha ditingkatkan dengan mendorong pembeli untuk membeli barang-barang dari penyalur perusahaan.

3) Technical Selling

Technical Selling berusaha meningkatkan penjualan dengan pemberian saran dan nasehat kepada pembeli akhir dari barang dan jasanya.

4) New Bussiness Selling

New Bussiness Selling berusaha membuka transaksi baru dengan merubah calon pembeli menjadi pembeli.

5) Responsive Selling Responsive Selling setiap tenaga penjualan diharapkan dapat memberikan reaksi terhadap permintaan pembeli.

c. Tahap-tahap Penjualan

Tahap-tahap penjualan menurut Basu Swastha (2009:121-124) antara lain sebagai berikut :

1) Persiapan sebelum penjualan

Dalam penjualan tatap muka adalah mengadakan persiapan sebelum melakukan penjualan. Di sini, kegiatan yang dilakukan adalah mempersiapkan tenaga penjualan dengan memberikan pengertian tentang barang yang dijualnya, pasar yang dituju dan teknik-teknik penjualan yang harus dilakukan.

2) Penentuan lokasi pembeli potensial

Dengan menggunakan data pembeli yang lalu maupun sekarang, penjual dapat menentukan karakteristik calon pembeli atau pembeli potensialnya.

3) Pendekatan pendahuluan

Sebelum melakukan penjualan, penjual harus mempelajari semua masalah tentang individu atau perusahaan yang dapat diharapkan sebagai pembelinya.

4) Melakukan penjualan

Penjualan yang dilakukan bermula dari suatu usaha untuk memikat perhatian calon konsumen, kemudian diusahakan untuk mengetahui daya tarik atau minat mereka.

5) Pelayanan purna jual

Sebenarnya kegiatan penjualan tidak berakhir pada saat pesanan dari pembeli telah dipenuhi, tetapi masih perlu dilanjutkan dengan memberikan pelayanan atau servis kepada mereka.

d. Tujuan Penjualan

Dalam suatu perusahaan kegiatan penjualan adalah kegiatan yang penting, karena dengan adanya kegiatan penjualan tersebut maka akan terbentuk laba yang dapat menjamin kelangsungan hidup perusahaan.

Bagi perusahaan, pada umumnya mempunyai tiga tujuan umum dalam penjulan, menurut Basu Swastha (2009: 80) yaitu:

1) Mencapai volume penjualan tertentu.

2) Mendapat laba tertentu.

3) Menunjang pertumbuhan perusahaan.

e. Faktor-faktor yang Mempengaruhi Penjualan

Aktivitas penjualan banyak dipengaruhi oleh faktor tertentu yang dapat 
meningkatkan aktivitas perusahaan, oleh karena itu manajer penjualan perlu memperhatikan faktor-faktor yang mempengaruhi penjualan. Faktor-faktor yang mempengaruhi penjualan menurut Basu Swastha (2008:406-407) sebagai berikut:

1) Kondisi dan Kemampuan Penjual

Transaksi jual-beli atau pemindahan hak milik secara komersial atas barang dan jasa itu pada prinsipnya melibatkan dua pihak, yaitu penjual sebagai pihak pertama dan pembeli sebagai pihak kedua. Di sini, penjual harus dapat meyakinkan kepada pembelinya agar dapat berhasil mencapai sasaran penjualan yang diharapkan. Untuk maksud tersebut penjual harus memahami beberapa masalah penting yang sangat berkaitan, yakni:

a) Jenis dan karakteristik barang yang ditawarkan.

b) Harga produk.

c) Syarat penjualan, seperti: pembayaran, penghantaran, layanan sesudah penjualan, garansi, dan sebagainya.

2) Kondisi Pasar

Pasar, sebagai kelompok pembelian atau pihak yang menjadi sasaran dalam penjualan, dapat pula mempengaruhi kegiatan penjualannya.

3) Modal

Akan lebih sulit bagi penjual untuk menjual barangnya apabila barang yang dijual tersebut belum dikenal oleh calon pembeli, atau apabila lokasi pembeli jauh dari tempat penjual. alam keadaan seperti ini, penjual harus memperkenalkan dulu membawa barangnya ke tempat pembeli. Untuk melaksanakan maksud tersebut diperlukan adanya sarana serta usaha, seperti: alat transport, tempat peragaan baik di dalam perusahaan maupun di luar perusahaan, usaha promosi, dan sebagainya. Semua ini hanya dapat dilakukan apabila penjual memiliki sejumlah modal yang diperlukan untuk itu.

4) Kondisi Organisasi Perusahaan

Pada perusahan yang besar, biasanya masalah penjualan ini ditangani oleh bagian tersendiri (Bagian Penjualan) yang dipegang orang-orang tertentu/ahli di bidang penjualan.

5) Faktor-faktor lain

Faktor-faktor lain seperti periklanan, peragaan, kampanye, dan pemberian hadiah sering mempengaruhi penjualan. Bilamana prinsip tersebut dilaksanakan, maka diharapkan pembeli akan kembali membeli lagi barang yang sama.

6) Pendidikan

Perusahaan pada era globalisasi sekarang ini menyatakan bahwa institusi pendidikan tinggi menjadi motor dari kemakmuran. Pendidikan pada tingkat ini dianggap sebagai kunci dari upaya peningkatan posisi suatu bangsa dalam persaingan global.

Perusahaan membutuhkan tenaga kerja dengan tingkat edukasi tinggi serta memiliki keahlian sebagai karyawan mereka untuk meningkatkan penjualan dan keuntungan. Perusahaan juga membutuhkan kurikulum yang dapat mendukumg tenaga kerja tersebut agar siap dengan relevansi pekerjaan mereka nanti. Hal ini menyebabkan institusi pendidikan tinggi mendapatkan tuntutan lebih dari dunia industri. Bukan sekedar menyediakan produk atau jasa tradisional mereka yaitu jasa pendidikan, namun juga permitraan atas penelitian (research) yang dapat diaplikasikan serta transfer ilmu serta teknologi bagi dunia industri.

Faktor pendidikan memegang peranan penting. Dengan adanya tenaga kerja memiliki kompetensi yang tinggi jelas akan meningkatkan 
penjualan. Kompetensi yang unggul dapat pula dikembangkan dengan adanya pendidikan dan latihan yang diselenggarakan oleh perusahaan.

Menurut Redaksi RAS (2009:19) ada tiga faktor yang mempengaruhi penjualan, yaitu kegiatan pemasaran, periklanan, dan jejaring usaha (networking).

\section{Tingkat Pendidikan Karyawan}

a. Pengertian Tingkat Pendidikan

1) Tingkat Pendidikan Karyawan

Tingkat pendidikan adalah suatu proses jangka panjang yang menggunakan prosedur sistematis dan terorganisir, yang mana tenaga kerja manajerial mempelajari pengetahuan konseptual dan teoritis untuk tujuantujuan umum.

Menurut Siswanto Sastro Hadiwiryo (2005:200) "Jenis pendidikan dan pelatihan yang disesuaikan dengan perusahaan khusus bergantung kepada beberapa faktor, seperti kecakapan yang diperlukan dalam jabatan/pekerjaan yang harus diisi dan masalah yang diharapkan dapat diperoleh jalan pemecahannya pada perusahaan."

Pendidikan adalah usaha sadar dan terencana untuk mewujudkan suasana belajar dan proses pembelajaran agar peserta didik secara aktif mengembangkan potensi dirinya untuk memiliki kekuatan spiritual keagamaan, pengendalian diri, kepribadian, kecerdasan, akhlak mulia, serta keterampilan yang diperlukan dirinya, masyarakat, bangsa dan negara. (UU RI No. 20 Tahun 2003 tentang Sistem Pendidikan Nasional, pasal 1)

2) Unsur-unsur Pendidikan

a) Input Sasaran pendidikan, yaitu: individu, kelompok, masyarakat.

b) Pendidik yaitu pelaku pendidikan. c) Proses yaitu upaya yang direncanakan untuk mempengaruhi orang lain.

d) Output yaitu melakukan apa yang diharapkan/perilaku.

3) Jalur Pendidikan

Menurut UU RI No. 20 Tahun 2003, jalur pendidikan dibagi menjadi:

a) Jalur Formal

Pasal 1 ayat 11, "Pendidikan formal adalah jalur pendidikan yang terstruktur dan berjenjang yang terdiri atas pendidikan dasar, pendidikan menengah, dan pendidikan tinggi."

(1) Pendidikan Dasar, Pendidikan dasar berbentuk Sekolah Dasar (SD) dan Madrasah Ibtidaiyah atau bentuk lain yang sederajat serta Sekolah Menengah Pertama (SMP) dan Madrasah Tsanawiyah (MTs) atau bentuk lain yang sederajat.

(2) Pendidikan Menengah, Pendidikan menengah terdiri atas pendidikan menengah umum dan pendidikan menengah jurusan, seperti: SMA, MA, SMK, MAK atau bentuk lain yang sederajat.

(3) Pendidikan Tinggi, Pendidikan tinggi dapat berbentuk akademi, politeknik, sekolah tinggi, institut dan universitas.

b) Jalur Nonformal

Pasal 26 ayat 1, "Pendidikan Nonformal diselenggarakan bagi warga masyarakat yang memerlukan layanan pendidikan yang berfungsi sebagai pengganti, menambah, dan/atau pelengkap pendidikan formal dalam rangka mendukung pendidikan sepanjang hayat."

c) Jalur Informal

Pasal 1 ayat 7 "Jalur pendidikan adalah wahana yang dilalui peserta didik untuk mengembangkan 
potensi diri dalam suatu proses pendidikan yang sesuai dengan tujuan pendidikan". Dari pengertian tersebut dapat disimpulkan bahwa pendidikan informal atau pendidikan dalam lingkup keuarga termasuk dalam salah satu jenjang atau tingkatan pendidikan yang harus dilalui oleh seorang anak dalam rangka proses penempaan diri untuk menjadi manusia dewasa.

Pendidikan nonformal adalah pendidikan yang dilakukan secara teratur, dengan sadar dilakukan, tetapi tidak terlalu ketat mengikuti peraturanperaturan yang tetap, seperti pada pendidikan formal di sekolah. Karena pendidikan nonformal pada umumnya dilaksanakan tidak dalam lingkungan fisik sekolah, maka pendidikan non formal diidentikkan dengan pendidikan luar sekolah. Oleh karena itu pendidikan nonformal dilakukan di luar sekolah, maka sasaran pokok adalah anggota masyarakat.

Program pendidikan nonformal harus dibuat sedemikian rupa agar bersifat luwes tetapi lugas, namun tetap menarik minat para konsumen pendidikan. Berdasarkan penelitian di lapangan, pendidikan nonformal sangat dibutuhkan oleh anggota masyarakat yang belum sempat mendapat kesempatan untuk mengikuti pendidikan formal karena sudah terlanjur lewat umur atau terpaksa putus sekolah, karena suatu hal.

Akhirnya tujuan terpenting dari pendidikan non-formal adalah program-program yang didasarkan kepada masyarakat harus sejalan dan terintegrasi dengan program-program pembangunan yang dibutuhkan oleh rakyat. Untuk menjembatani kesenjangan ini, peran pendidikan non- formal dan informal (PNFI) sangatlah penting.

Anak-anak yang tidak memiliki kesempatan mengikuti pendidikan formal sepatutnya sebanyak mungkin dijangkau melalui PNFI agar mereka mendapat pembekalan yang memadai untuk kehidupannya. PNFI dapat menjawab kebutuhan pendidikan yang disesuaikan dengan konteks lokal masyarakat setempat yang tidak dapat dijawab oleh pendidikan formal.

Menurut Siswanto Sastro Hadiwiryo (2005:200) pendidikan dan pelatihan dapat dibedakan menjadi beberapa jenis, yaitu pendidikan umum, pendidikan kejuruan, pelatihan keahlian dan pelatihan kejuruan.

b. Pengertian Karyawan

Menurut Undang-Undang No. 13 tahun 2003 (pasal 1, ayat 2) "Tentang ketenagakerjaan dikatakan bahwa Tenaga kerja adalah setiap orang yang mampu melakukan pekerjaan guna menghasilkan barang dan/atau jasa baik untuk memenuhi kebutuhan sendiri maupun untuk masyarakat."

Karyawan merupakan kekayaan utama dalam suatu perusahaan, karena tanpa adanya keikutsertaan mereka, aktifitas perusahaan tidak akan terlaksana.

c. Tingkat Pendidikan Karyawan

Dunia usaha merupakan tempat dimana pengetahuan dan kemampuan sangatlah dibutuhkan, dibutuhkan karyawan yang memiliki ilmu pengetahuan yang cukup sebagai tenaga ahli dan mampu menangani masalah yang dihadapi oleh perusahaannya. Hal ini dipengaruhi oleh tingkat pendidikan yang dimiliki oleh karyawan itu sendiri.

Menurut Prijono Tjipto Heridjanto (2008:105) bahwa tingkat pendidikan bagi tenaga kerja akan memberikan pengetahuan bukan saja yang langsung dengan pelaksanaan tugas pekerjaan, akan tetapi, 
juga landasan untuk mengembangkan diri serta kemampuan memanfaatkan semua sarana untuk kelancaran tugas atau pekerjaan.

Indikator tingkat pendidikan terdiri dari jenjang pendidikan dan kesesuaian jurusan. Menurut UU No. 20 Tahun 2003 (pasal 1, ayat 8) Jenjang pendidikan adalah tahapan pendidikan yang ditetapkan berdasarkan tingkat perkembangan peserta didik, tujuan yang akan dicapai, dan kemampuan yang dikembangkan.

Jenjang pendidikan terdiri dari:

1) Pendidikan dasar: Jenjang pendidikan awal selama 9 (sembilan) tahun pertama masa sekolah anak-anak yang melandasi jenjang pendidikan menengah.

2) Pendidikan menengah: Jenjang pendidikan lanjutan pendidikan dasar.

3) Pendidikan tinggi: Jenjang pendidikan setelah pendidikan menengah yang mencakup program sarjana, magister, doktor, dan spesialis yang diselenggarakan oleh perguruan tinggi.

Kesesuaian jurusan adalah sebelum karyawan direkrut terlebih dahulu perusahaan menganalisis tingkat pendidikan dan kesesuaian jurusan pendidikan karyawan tersebut agar nantinya dapat ditempatkan pada posisi jabatan yang sesuai dengan kualifikasi pendidikannya tersebut. Dengan demikian karyawan dapat memberikan kinerja yang baik bagi perusahaan.

d. Faktor-Faktor yang Mempengaruhi Tingkat Pendidikan

Tingkat pendidikan merupakan sebuah skala atau ukuran dari adanya kompetensi yang dimiliki oleh peserta didik. Peserta didik sendiri dalam proses pembelajaran agar dapat melanjutkan pada tingkat pendidikan selanjutnya memiliki beberapa faktor. Faktor-faktor tersebut yang menentukan peserta didik layak atau tidak naik pada tingkatan selanjutnya. Faktor yang menentukan tingkat pendidikan adalah:
1) Usia

Usia adalah yang terhitung mulai saat dilahirkan sampai saat ia akan berulang tahun. Berbagai macam pendidikan atau sekolah dibatasi oleh umur. Sehingga umur mempengaruhi seseorang dalam mengakses pendidikan.

2) Pekerjaan

Pekerjaan adalah serangkaian tugas atau kegiatan yang harus dilaksanakan atau diselesaikan oleh seseorang sesuai dengan jabatan atau profesi masing-masing. Status pekerjaan yang rendah mempengaruhi tingkat pendidikan seseorang.

3) Status Ekonomi

Status ekonomi berpengaruh terhadap status pendidikannya. Individu yang berasal dari keluarga yang status ekonominya menengah dan tinggi dimungkinkan lebih memiliki pendidikan yang tinggi pula.

4) Sosial Budaya

Lingkungan sosial budaya mengandung dua unsur yaitu yang berarti interaksi antara manusia dan unsur budaya yaitu bentuk kelakuan yang sama terdapat di keluarga. Manusia mempelajari kelakuannya dari orang lain di lingkungan sosialnya. Budaya ini diterima dalam keluarga meliputi bahasa dan nilai-nilai kelakuan adaptasi kebiasaan dan sebagainya yang nantinya berpengaruh pada pendidikan seseorang.

5) Lingkungan

Lingkungan adalah seluruh kondisi yang ada di sekitar manusia dan pengaruhnya yang dapat mempengaruhi perkembangan dan perilaku orang atau kelompok. Lingkungan adalah input ke dalam diri seseorang sehingga sistem adaptasi yang melibatkan baik faktor internal maupun faktor eksternal. Seseorang yang hidup dalam lingkungan berpendidikan tinggi akan 
cenderung untuk mengikuti lingkungannya. (http://fourseasonnews. blogspot.com/2012/05/faktor-yangmempengaruhi-tingkat.htm , diunduh.20/04/2013)

Dari 5 faktor di atas dapat diketahui bahwa tingkat pendidikan tidak hanya ditentukan dari pribadi namun juga mencakup 5 aspek di atas. Apabila dalam 5 aspek di atas tidak terpenuhi maka tingkat pendidikan yang didapat tidak sampai pada jenjang yang lebih tinggi. Hal ini sesuai apabila seseorang merasa cukup dengan hasil yang didapat sekarang maka keinginan untuk mencari ilmu di bangku pendidikan juga akan menurun.

\section{Persekutuan Komanditer (CV)}

a. Pengertian Persekutuan Komanditer CV

Penelitian ini akan membahas secara umum dan ilmiah mengenai persekutuan komanditer atau CV dalam sebuah pendirian usaha persekutuan, diperlukan adanya penyokong dana yang memberikan modal usaha baik uang, barang, dan tenaga yang dapat menjalankan persekutuan komanditer itu sendiri.

Persekutuan Komanditer (commanditaire vennootschap atau $\mathrm{CV}$ ) adalah suatu persekutuan yang didirikan oleh seorang atau beberapa orang yang mempercayakan uang atau barang kepada seorang atau beberapa orang yang menjalankan perusahaan dan bertindak sebagai pemimpin.

Menurut Bambang Prishardoyo (2005:105) menyatakan bahwa "Persekutuan Komanditer (CV) didirikan oleh beberapa orang sebagaimana mendirikan firma. Didirikan di hadapan notaris untuk dibuatkan akte pendiriannya. Apabila pendirinya sebagai pemilik ingin memperbesar modal perusahaan dan tidak menghendaki kepemimpinannya dicampuri oleh orang lain, maka akan diterbitkan surat-surat sero atau saham yang kemudian dijual kepada masyarakat yang membutuhkan."

Berdasarkan pendapat ahli di atas dapat disimpulkan, CV merupakan persekutuan dari firma. Usahanya berjalan dengan menggunakan nama yang sama. Persekutuan komanditer sendiri dapat berjalan apabila ada pihak yang memberikan modal kepada seseorang untuk dijalankan usahanya. Pemilik modal tidak langsung ikut terjun dalam menjalankan usahanya.

b. Bentuk Persekutuan Komanditer

Menurut Bambang Prishardoyo (2005:106) Berdasarkan uraian di atas, dalam perseroan komanditer terdapat dua jenis persero atau pemegang saham, yaitu:

1) Sekutu Aktif atau Persero Pengurus (Managing Partner)

Adalah persero yang bertugas mengurus, mengelola, dan bertanggung jawab atas maju mundurnya perusahaan. Persero ini disebut persero pengurus yang memegang pimpinan perusahaan dan bertanggung jawab penuh atas jalannya perusahaan. Selain memasukkan modal para perusahaan, persero ini juga bertanggung jawab penuh atas kewajiban atau utang-utang perusahaan dengan seluruh harta bendanya, baik harta yang ditanamkan pada perusahaan maupun harta pribadi yang lain.

2) Sekutu Pasif atau Komanditer (Sleeping Partner)

Persero yang hanya berperan memasukkan modalnya pada perusahaan dengan mengharapkan bunga atau bagian keuntungan $\mathrm{CV}$ yang disebut deviden. Persero ini tidak diperkenankan mencampuri atau ikut campur dalam usaha yang dilakukan perusahaan $(\mathrm{CV})$ oleh persero aktif. Apabila perusahaan menderita kerugian atau gulung tikar, persero aktif ikut bertanggung jawab yang terbatas pada besar modal yang 
ditanamkan saja, harta milik pribadinya tidak diganggu dan tidak digunakan sebagai jaminan utang.

Persekutuan komanditer biasanya didirikan dengan akta dan harus didaftarkan. Namun persekutuan ini bukan merupakan badan hukum (sama dengan firma), sehingga tidak memiliki kekayaan sendiri.

\section{Pengaruh Tingkat Pendidikan Karyawan Terhadap Penjualan Pupuk pada CV. Pandan Wangi}

Dalam hal usaha pasti melihat bagian laba rugi dari proses yang dilakukan. Dengan jalan melihat berapa besar produk jadi yang telah dipasarkan seseorang akan tahu berapa pendapatan yang diperoleh dalam satu kali produksi. Hal ini tidak lepas dari adanya kegigihan karyawan yang secara langsung berdekatan dengan konsumen, untuk menawarkan produk yang dijual.

Karyawan atau pegawai merupakan ujung tombak dimana suatu perusahaan tersebut mampu beroperasi atau tidak. Tanpa adanya tenaga kerja atau karyawan, jelas proses produksi dan penjualan tidak akan berlangsung secara optimal dan sesuai dengan harapan. Untuk itu, persekutuan komanditer dalam proses rekruitmen tidak langsung tebang pilih dalam menerima karyawan. Dibutuhkan adanya tenaga ahli yang jelas memiliki keahlian yang cukup dan disertai ijazah terakhir yang dimiliki.

Hal ini secara langsung berpengaruh terhadap peningkatan penjualan yang dilakukan oleh persekutuan komanditer. Dengan ditunjang tenaga ahli yang dimiliki, konsumen akan lebih tertarik dan percaya dengan produk yang ditawarkan.

Pencapaian pendidikan akan membentuk dan menambah pengetahuan seseorang untuk mengerjakan sesuatu dengan lebih cepat dan tepat. Sementara pelatihan akan membentuk dan mening- katkan keterampilan tenaga kerja. Dengan demikian semakin tinggi tingkat pendidikan dan latihan seseorang, semakin tinggi tingkat produktivitasnya.

Sesuai dengan pendapat di atas, dapat ditarik kesimpulan bahwa Tingkat pendidikan berpengaruh terhadap tingkat penjualan. Karena, apabila sumber daya manusia yang dimiliki persekutuan komanditer tidak memiliki keahlian serta pendidikan yang tinggi jelas tidak akan mampu bekerja dam mengukur besar pendapatan dari waktu tertentu sehingga persekutuan komanditer dalam waktu tertentu akan mengalami kerugian.

\section{Kerangka Pemikiran}

Penelitian ini bertujuan mengungkap pengaruh adanya tingkat pendidikan terhadap penjualan persekutuan komanditer pada CV. Pandan Wangi. Masalah yang ditemui dalam hal ini bahwa tingkat pendidikan erat kaitannya dengan kualitas kerja karyawan. Dengan semakin tinggi kompetensi yang dimiliki oleh karyawan tentu akan memberikan kontribusi yang lebih besar kepada persekutuan komanditer.

Perseroan komanditer adalah suatu perseroan untuk menjalankan suatu perusahaan yang dibentuk satu orang atau beberapa orang pesero yang secara tanggung menanggung bertanggung-jawab untuk seluruhnya (tanggung jawab solider) pada satu pihak, dan satu orang atau lebih sebagai pelepas uang (geldscheiter) pada pihak yang lain.

Pada dasarnya persekutuan komanditer (Commanditaire Vennotschap) adalah persekutuan firma yang mempunyai satu atau lebih sekutu komanditer. Sekutu komanditer sendiri adalah sekutu yang hanya menyerahkan uang disebut juga "geldschieter" (pelepas uang) atau barang sebagai pemasukan (inbreng) pada persekutuan dan ia tidak turut serta dalam pengurusan atau penguasaan dalam persekutuan.

Sehingga jelas, dalam menjalankan 
usaha ini dibutuhkan tenaga ahli yang cakap dan tanggap dalam menggunakan modal yang telah diberikan. Jelas tidak memungkinkan bahwa dalam menjalankan usaha, tidak didukung adanya kompetensi-kompetensi unggul yang dimiliki karyawan.

Mengacu pada telah pustaka yang telah diuraikan di atas, maka penulis mengidentifikasi adanya pengaruh tingkat pendidikan dalam perusahaan sebagai variabel independen (bebas) dengan permasalahan utama yaitu peningkatan hasil penjualan sebagai variabel dependen (terikat), dengan adanya tingkat pendidikan yang tinggi diharapkan proses penjualan suatu produk pupuk dapat mencapai tingkat penjualan yang tinggi.

Kerangka pemikiran teoristis digambarkan dalam model seperti pada gambar berikut:

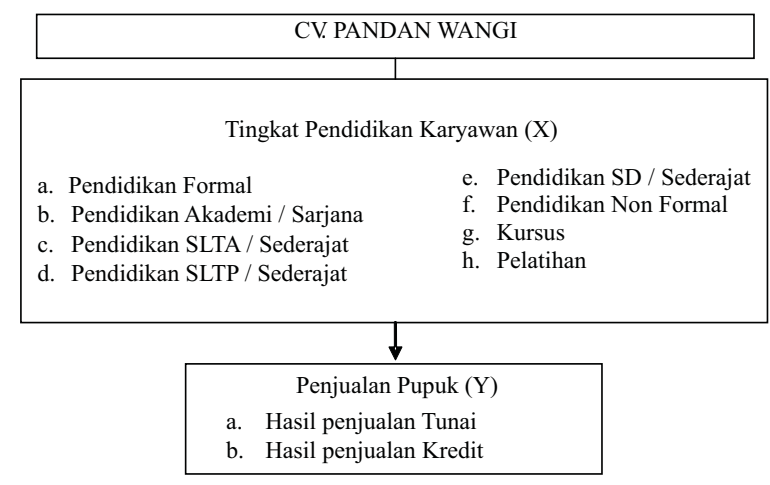

Gambar 2.1 Kerangka Berpikir

\section{Hipotesis Penelitian}

Hipotesis penelitian merupakan jawaban dari perumusan masalah yang diajukan serta perlu pembuktian lebih lanjut tentang kebenarannya. Menurut Nanang (2010:57) Hipotesis adalah jawaban sementara yang kebenarannya masih harus di uji atau rangkuman kesimpulan teoritis yang diperoleh dari tinjauan pustaka. Dalam penelitian ini hipotesis yang diangkat adalah:

Ha diterima tingkat pendidikan karyawan berpengaruh terhadap penjualan pupuk.

$\mathrm{H}_{0}$ ditolak tingkat pendidikan karyawan tidak berpengaruh terhadap penjualan pupuk.

Apabila $\mathrm{T}_{\text {hitung }}>\mathrm{T}_{\text {tabel }}=\mathrm{H}_{0}$ ditolak, Ha diterima, maka hipotesisnya "ada pengaruh yang signifikan antara tingkat pendidikan karyawan terhadap penjualan pupuk". Apabila $\mathrm{T}_{\text {hitung }}<\mathrm{T}_{\text {tabel }}=\mathrm{H}_{0}$ diterima, Ha ditolak, maka hipotesisnya "tidak ada pengaruh yang signifikan antara tingkat pendidikan karyawan terhadap penjualan pupuk".

\section{METODE PENELITIAN}

\section{Tempat dan Waktu Penelitian}

1. Tempat Penelitian

Penelitian ini dilakukan pada CV. Pandan Wangi dengan alamat Jln. Raya Caruban-Ngawi km. 5 Desa Pulerejo RT/ RW:12/02 Kecamatan Pilangkenceng Kabupaten Madiun. Pertimbangan peneliti memilih tempat penelitian ini antara lain:

a. Terdapat permasalahan yang perlu diteliti.

b. Tersedia data yang dibutuhkan yang sesuai dengan permasalahan yang diteliti.

c. Belum pernah diadakan penelitian tentang pengaruh tingkat pendidikan terhadap peningkatan penjualan.

d. Pihak CV. Pandan Wangi Kabupaten Madiun mudah diajak berkoordinasi dalam melakukan penelitian.

2. Waktu Penelitian

Waktu penelitian merupakan jangka waktu yang digunakan oleh seorang peneliti dalam melakukan kegiatan penelitian, yaitu dimulai dari penyusunan sampai penulisan laporan hasil penelitian berjalan dan terprogram. Penelitian dilaksanakan pada bulan September 2013 sampai dengan Februari 2014 dengan jadwal sebagai berikut:

\section{Tabel 3.1 Jadwal Penelitian}

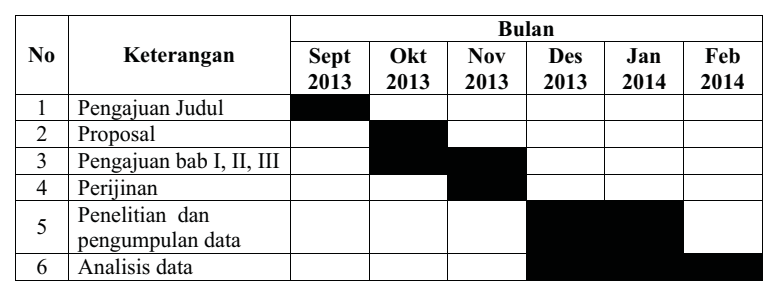




\section{Desain Penelitian}

Rancangan penelitian adalah strategi mengatur proses penelitian agar peneliti memperoleh data yang valid sesuai dengan karakteristik variabel dan tujuan penelitian. Dalam rancangan penelitian dijelaskan variable-variabel yang dilibatkan dalam penelitian serta sifat hubungan antara variabel variabel tersebut (Tim IKIP PGRI Madiun, 2012:23).

Penelitian ini menggunakan rancangan penelitian kuantitatif, penelitian kuantitatif dapat diartikan sebagai metode penelitian yang berlandaskan pada filsafat positifisme, digunakan untuk meneliti pada populasi atau sample tertentu, pengumpulan data menggunakan instrument penelitian, analisis data bersifat kuantitatif/statistik, dengan tujuan untuk menguji hipotesis yang telah ditetapkan. (Sugiyono, 2007: 8) berikut:

Langkah-langkah penelitian sebagai

1. Mendefinisikan dengan jelas dan spesifik tujuan yang akan dicapai

2. Merancang cara pendekatan

3. Mengumpulkan data

4. Menyusun laporan penelitian

Desain Penelitian seperti berikut:

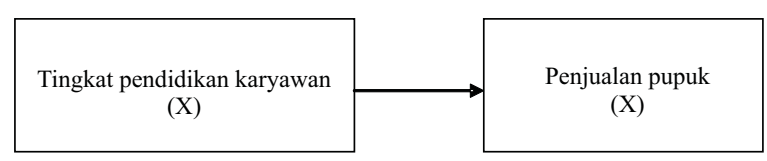

Gambar 3.1 Desain Penelitian

Variabel-variabel yang dilibatkan dalam penelitian ini adalah:

1. Variabel bebas (variabel independen)

Menurut Sugiyono (2010:61)

"Variabel bebas adalah merupakan variabel yang mempengaruhi atau yang menjadi sebab perubahannya atau timbulnya variabel dependen (terikat)".

Variabel bebas adalah variabel yang menentukan arah atau perubahan tertentu pada variabel tergantung, sementara variabel bebas berada pada posisi yang lepas dari "pengaruh" variabel tergantung".
Penulis menyimpulkan variabel bebas adalah variabel yang mempengaruhi atau menjelaskan variabel yang lain.

Yang dipergunakan sebagai variabel independen atau variabel bebas dalam penelitian ini adalah tingkat pendidikan karyawan (X) dalam bentuk bukti fisik ijazah.

2. Variabel variabel (terikat dependen)

Sugiyono (2010:61) "variabel terikat merupakan variabel yang dipengaruhi atau yang menjadi akibat karena adanya variabel bebas."

Yang dipergunakan sebagai variabel dependen atau variabel terikat dalam penelitian ini adalah Penjualan Pupuk (Y) dalam bentuk satuan ton pada jumlah penjualan pupuk CV. Pandan Wangi Kabupaten Madiun.

\section{Populasi, Sample, Teknik Ppengambilan Sample}

1. Populasi

Populasi yaitu sekumpulan obyek yang dijadikan sebagai bahan penelitian dengan ciri mempunyai karakteristik yang sama.

Sugiyono (2010:117) berpendapat bahwa populasi adalah wilayah generalisasi yang terdiri atas obyek/subyek yang mempunyai kualitas dan karakteristik tertentu yang ditetapkan oleh peneliti untuk dipelajari dan kemudian ditarik kesimpulannya.

Dalam penelitian ini yang menjadi populasi adalah jumlah keseluruhan karyawan sebesar 40 orang pada CV. Pandan Wangi Kabupaten Madiun, sekaligus laporan penjualan.

2. Sampel

Sampel adalah sebagian atau wakil populasi yang diteliti (Suharsimi 2010: 174).

Sugiyono (2010:118) “sampel adalah bagian dari jumlah atau karakteristik yang dimiliki oleh populasi 
tersebut". Dalam penelitian ini yang dijadikan sampel adalah tingkat pendidikan karyawan sebesar 40 orang dan penjualan pupuk pada tahun 2013.

3. Teknik pengambilan sampel

Sugiyono (2010:118-119) "Teknik sampling adalah merupakan teknik pengambilan sampel. Untuk menentukan sampel yang akan digunakan penelitian, terdapat berbagai teknik sampling yang digunakan".

Pengambilan sampel ini harus dilakukan sedemikian rupa sehingga diperoleh sampel (contoh) yang benarbenar berfungsi sebagai contoh, atau dapat menggambarkan keadaan populasi yang sebenarnya.

Metode penentuan sampel yang digunakan dalam penelitian ini adalah metode sampel jenuh. Metode sampel jenuh adalah teknik penentuan sampel bila semua anggota populasi digunakan menjadi sampel. Dalam penelitian ini yang menjadi sample jenuh adalah keseluruhan karyawan CV. Pandan Wangi Kabupaten Madiun.

Berpatokan dari pendapat di atas, dengan adanya jumlah karyawan sebesar 40 orang, maka pengambilan sample didasarkan pada besar populasi yang bekerja di CV. Pandan Wangi Kabupaten Madiun.

\section{Tekhnik Pengumpulan Data}

Tekhnik pengumpulan data dengan menggunakan:

1. Metode Dokumentasi

Dokumentasi menurut Suharsimi Arikunto, (2010:201) "Di dalam melaksanakan metode dokumentasi, peneliti menyelidiki benda-benda tertulis seperti buku-buku, majalah, dokumen dan peraturan-peraturan, notulen rapat, cacatan harian dan sebagainya".

Metode Dokumentasi adalah metode pengumpulan data yang penyelidikannya ditujukan pada penguraian apa yang telah lalu, melalui sumber-sumber dokumen. Dengan metode ini diharapkan penulis bisa mendapatkan informasi data yang diperlukan dan yang berhubungan dengan penelitian berupa:

a. Tingkat pendidikan karyawan dari variabel $\mathrm{X}$, pada data dokumentasi ini akan didasarkan pada jenjang pendidikan mulai dari SD, SMP, SMA/SMK, D3, S1. Untuk mengetahui tingkat pendidikan keseluruhan karyawan di CV. Pandan Wangi.

Tabel 3.2. Skor Tingkat Pendidikan Karyawan CV. Pandan Wangi

\begin{tabular}{|c|l|c|}
\hline No. & Jenjang Pendidikan & Skor \\
\hline 1 & SD & 1 \\
\hline 2 & SMP & 2 \\
\hline 3 & SMA & 3 \\
\hline 4 & DIPLOMA & 4 \\
\hline 5 & S1 & 5 \\
\hline
\end{tabular}

b. Variabel Penjualan dari variabel Y, Variabel penjualan di dasarkan pada penjualan tiap karyawan dalam bentuk satuan ton.

2. Metode Interview

Menurut Suharsimi Arikunto, (2010: 198) "Interview yang sering juga disebut dengan wawancara atau kuisioner lisan, adalah sebuah dialog yang dilakukan oleh pewawancara (interviewer) untuk memperoleh informasi dari terwawancara (interviewer)".

Dengan metode ini diharapkan penulis mendapatkan data berupa:

a. Tingkat pendidikan karyawan, yang didasarkan pada strata pendidikan, data yang diambil diuraikan struktur organisasi.

b. Penjualan berdasarkan pada laporan penjualan tahunan, dan dalam bentuk satuan ton. Dengan adanya data ini akan diketahui berapa jumlah penjualan yang dibandingkan dengan tingkat pendidikan tiap karyawan CV. Pandan Wangi. 


\section{Instrumen Penelitian}

Instrumen penelitian adalah alat atau fasilitas yang digunakan oleh peneliti dalam mengumpulkan data agar pekerjaannya lebih mudah dan hasilnya lebih baik (Suharsimi Arikunto, 2010:203). Instrumen yang digunakan dalam penelitian ini menggunakan pedoman wawancara dan dokumentasi.

Dalam penelitian ini peneliti menggunakan Instrumen penelitian berupa pedoman wawancara berupa pertanyaanpertanyaan yang berkaitan dengan tingkat pendidikan karyawan dan penjualan pupuk di CV. Pandan Wangi.

\section{Teknik Analisis Data}

1. Metode Analisis Regresi Linier Sederhana Setelah data penelitian terkumpul, selanjutnya adalah menganalisis data tersebut melalui perhitungan statistik untuk menguji hipotesis dan mencari koefisien pengaruh tingkat pendidikan karyawa terhadap penjualan pupuk. Penelitian ini menggunakan regresi linier sederhana dimaksudkan untuk mengetahui pengaruh antara tingkat pendidikan karyawan (X) terhadap penjualan pupuk (Y) dalam bentuk persamaan regresi.

Rumus dari bentuk persamaan regresi linier sederhana adalah sebagai berikut:

$Y=a+b X$

$a=\frac{\sum Y\left(\sum X^{2}\right)-\sum X \sum X Y}{n \sum X^{2}-\left(\sum X^{2}\right)}$

$b=\frac{n\left(\sum X Y\right)-\left(\sum X\right)\left(\sum Y\right)}{n\left(\sum X^{2}\right)-\left(\sum X\right)^{2}}$

(Husein Umar, 2011:114)

Keterangan:

$\mathrm{Y}=$ Tingkat pendidikan karyawan

$\mathrm{X}=$ Penjualan pupuk

$\mathrm{a}=$ Bilangan intercept (konstan)

$\mathrm{b}=$ Koefisien arah regresi

2. Uji Hipotesis
a. Uji Korelasi

Moehar Daniel (2003:154) "Uji
Korelasi digunakan untuk mencari keeratan hubungan antara dua variabel".

Rumus dan kriteria adalah sebagai berikut :

$r=\frac{n \sum X Y-\left(\sum X\right)\left(\sum Y\right)}{\sqrt{\left\{n \sum X^{2}-\left(\sum X\right)^{2}\right\}\left\{n \sum Y^{2}-\left(\sum Y\right)^{2}\right\}}}$

(Iqbal Hasan, 2004:61)

Keterangan:

$\mathrm{r}=$ Koefisien korelasi Pearson

$\mathrm{X}=$ Variabel bebas

$\mathrm{Y}=$ Variabel terikat

Uji korelasi dalam penelitian ini digunakan kriteria dengan terlebih dahulu menentukan hipotesisnya. Hipotesis yang digunakan dalam penelitian ini adalah sebagai berikut:

1) $H_{0}$ ditolak apabila nilai $r_{\text {hitung }} \geq r_{\text {tabel }}$ dapat diartikan ada hubungan tingkat pendidikan karyawan dengan penjualan pupuk pada CV. Pandan Wangi Kabupaten Madiun.

2) $\mathrm{H}_{0}$ diterima apabila nilai $\mathrm{r}_{\text {hitung }}<\mathrm{r}_{\text {tabel }}$ dapat diartikan tidak ada hubungan tingkat pendidikan karyawan dengan penjualan pupuk pada CV. Pandan Wangi Kabupaten Madiun.

b. Uji Fisher

Uji Fisher atau uji F yaitu "alat analisis untuk mengetahui apakah semua variabel bebas secara bersamasama mempunyai pengaruh signifikan terhadap variabel terikatnya" (Gabriel Amin, 2003: 86).

Rumus Uji Fisher :

$F=\frac{R J K_{\text {reg }(b / a)}}{R J K_{\text {res }}}$

Keterangan:

$\mathrm{F} \quad$ : Fisher

$R J K_{\text {(reg(b/a) }}$ : Rata-rata jumlah kuadrat regresi (b/a)

$R J K_{\text {res }} \quad$ : Rata-rata jumlah kuadrat residu

(Juliansyah Noor, 2011:183) 
Uji Fisher dalam penelitian ini digunakan kriteria dengan terlebih dahulu menentukan hipotesisnya. Hipotesis yang digunakan dalam penelitian ini adalah sebagai berikut:

a. $\mathrm{H}_{0}$ ditolak apabila nilai $\mathrm{F}_{\text {hitung }} \geq \mathrm{F}_{\text {tabel }}$ dapat diartikan ada pengaruh tingkat pendidikan karyawan dengan penjualan pupuk pada CV. Pandan Wangi Kabupaten Madiun.

b. $\mathrm{H}_{0}$ diterima apabila nilai $\mathrm{F}_{\text {hitung }}<\mathrm{F}_{\text {tabel }}$ dapat diartikan tidak ada pengaruh tingkat pendidikan karyawan dengan penjualan pupuk pada $\mathrm{CV}$. Pandan Wangi Kabupaten Madiun.

c. Ujit

Uji t yaitu "alat analisis untuk mengetahui apakah variabel bebas secara individual mempunyai pengaruh yang signifikan terhadap variabel terikat" (Gabriel Amin, 2003:86).

Rumus Ujit :

$t_{\text {hitung }}=\frac{r \sqrt{n-2}}{\sqrt{1-r^{2}}}$

Keterangan:

$t_{\text {hitung }}=$ nilai $t_{\text {hitung }}$

$\mathrm{r}=$ koefisien korelasi untuk masing-masing item/butir instrumen

$\mathrm{n}=$ Jumlah responden

Kriteria ini digunakan dalam penelitian hipotesis untuk uji t. Hipotesis yang digunakan adalah sebagai berikut:

a. $\mathrm{H}_{0}$ ditolak apabila nilai $\mathrm{t}_{\text {hitung }} \geq \mathrm{t}_{\text {tabel }}$ dapat diartikan ada beda pengaruh tingkat pendidikan karyawan dengan penjualan pupuk pada $\mathrm{CV}$. Pandan Wangi Kabupaten Madiun.

b. $\mathrm{H}_{0}$ diterima apabila nilai $\mathrm{t}_{\text {hitung }}<\mathrm{t}_{\text {tabel }}$ dapat diartikan tidak ada beda pengaruh tingkat pendidikan karyawan dengan penjualan pupuk pada CV. Pandan Wangi Kabupaten Madiun.
Keseluruhan uji tersebut di atas, dalam menganalisisnya menggunakan alat bantu program SPSS (Statistical Product and Service Solution) for windows 17.0.

\section{HASIL PENELITIAN}

\section{Deskripsi Data}

CV. Pandan Wangi berdiri pada 11 Agustus 2009. Lokasi di Jalan Raya CarubanNgawi km.5 Desa Pulerejo RT/RW : 12/02 Kecamatan Pilangkenceng Kabupaten Madiun. Produk pupuk yang dihasilkan oleh CV. Pandan Wangi tersebut selanjutnya didistribusikan ke kios-kios penyangga.

1. Deskripsi tingkat pendidikan di CV. Pandan Wangi.

Diferensiasi jenjang pendidikan dalam sebuah usaha sangat diperlukan sesuai dengan kebutuhan perusahaan. Hal ini berpengaruh dari adanya sumber daya manusia yang siap bekerja dan mempunyai skill untuk meningkatkan penjualan di CV. Pandan Wangi. Dalam pola pekerjaan jelas dibutuhkan individu yang memiliki pengalaman baik di bangku pendidikan maupun otodidak. Sehingga tidak dapat disamakan jenis pekerjaan dengan tingkat pendidikan.

Berikut disampaikan tingkat pendidikan yang ada di CV. Pandan Wangi tahun anggaran 2013. (lampiran 4) lihat pada tabel 4.1 berikut :

Tabel 4.1 Deskripsi Tingkat Pendidikan Karyawan CV. Pandan Wangi

\begin{tabular}{|c|l|c|c|}
\hline No & \multicolumn{1}{|c|}{ Nama } & Pendidikan & Skor \\
\hline 1 & Ernita Rohmayanti, S.Sos. & S1 & 5 \\
\hline 2 & Nuning Udayanah Nurfiati, S.Sos. & S1 & 5 \\
\hline 3 & Syamsuri & S1 & 5 \\
\hline 4 & Ratna Hapsari Aningdyah & SMA & 3 \\
\hline 5 & Nurhidayati & SMA & 3 \\
\hline 6 & Yayak Muflihana Hanik & SMA & 3 \\
\hline 7 & Esti Puji Rahayu & SMA & 3 \\
\hline 8 & R. Wegig Wahana & SMA & 3 \\
\hline 9 & Sugeng & SMA & 3 \\
\hline 10 & Endah Tri Wahjuni, S.Sos. & S1 & 5 \\
\hline 11 & Didik Karmahendra & SMA & 3 \\
\hline 12 & Kasmuri & SMA & 3 \\
\hline 13 & Slamet & D3 & 3 \\
\hline 14 & Muhammad Mabror, A.Md. & SMA & 3 \\
\hline 15 & Ratna Handayani & & \\
\hline
\end{tabular}




\begin{tabular}{|c|l|c|c|}
\hline No & \multicolumn{1}{|c|}{ Nama } & Pendidikan & Skor \\
\hline 16 & Agung Witjaksono, & S1 & 5 \\
\hline 17 & Gamal Arfan Afandie & SMA & 3 \\
\hline 18 & Nanik Wuryaningsih & SMA & 3 \\
\hline 19 & Denny Dwi Indiarto & SMA & 3 \\
\hline 20 & Sulistyarini & SMA & 3 \\
\hline 21 & Sri Astati Murhani & SMA & 3 \\
\hline 22 & Slamet & SMA & 3 \\
\hline 23 & Imam Safi'i & SMA & 3 \\
\hline 24 & Suryono & SMA & 3 \\
\hline 25 & Soegijo & S1 & 3 \\
\hline 26 & Waidi, S.Sos & SMA & 3 \\
\hline 27 & Tutik Herlinawati & SMA & 3 \\
\hline 28 & Agus Setiyana & SMA & 3 \\
\hline 29 & Maskhuroh & SMA & 3 \\
\hline 30 & Martono & SMA & 3 \\
\hline 31 & Didik Srihardi & SMA & 3 \\
\hline 32 & Harsumi & SMA & 3 \\
\hline 33 & Bambang Basuki W & SMA & 3 \\
\hline 34 & Gunawan & SMA & 3 \\
\hline 35 & Esthi Purwanti BL & SMA & 3 \\
\hline 36 & Titik Suwartini & SMA & 3 \\
\hline 37 & Sri Yulistiyo & SMA & 3 \\
\hline 38 & Deddy Purnomo & 3 \\
\hline 39 & Sunarto & & \\
\hline 40 & Wahyu Muji L.B. & 3 \\
\hline & & SMA & 3 \\
\hline
\end{tabular}

Sumber : Data tingkat pendidikan karyawan CV.Pandan Wangi, 2013

Berdasarkan tabel 4.1 di atas, untuk mengetahui tingkat pendidikan karyawan CV. Pandan Wangi dianalisis menggunakan statistik deskriptif dengan alat bantu program SPSS for windows 17.0.

Tabel 4.2 Statistik Deskripsi Tingkat Pendidikan Karyawan

\begin{tabular}{|c|c|c|c|c|c|}
\hline & & Frequency & Percent & Valid Percent & \begin{tabular}{|l|} 
Cumulative \\
Percent
\end{tabular} \\
\hline \multirow[t]{4}{*}{ Valid } & SMA & 34 & 85.0 & 85.0 & 85.0 \\
\hline & D3 & 1 & 2.5 & 2.5 & 87.5 \\
\hline & s1 & 5 & 12.5 & 12.5 & 100.0 \\
\hline & Total & 40 & 100.0 & 100.0 & \\
\hline
\end{tabular}

Sumber: Data Tingkat Pendidikan Karyawan CV. Pandan Wangi, SPSS V.17

Dapat diketahui bahwa dari keseluruhan karyawan di CV. Pandan Wangi tingkat pendidikan karyawan yang memiliki jumlah terbanyak adalah SMA sebesar 34 oang, tingkat pendidikan S1 5 orang, tingkat pendidikan D3 berjumlah 1 orang.

2. Deskripsi Penjualan CV. Pandan Wangi

Penjualan di CV. Pandan Wangi pada tahun 2013 memiliki jumlah yang meningkat. Hal ini menunjukkan keseriusan karyawan dalam meningkatkan penjualan pada CV. Pandan Wangi.

Tabel 4.3 Deskripsi Penjualan Pupuk CV Pandan Wangi

\begin{tabular}{|c|c|c|}
\hline No. & Nama & Penjualan (ton) (Y) \\
\hline 1 & Ernita Rohmayanti, S.Sos. & 75 \\
\hline 2 & Nuning Udayanah Nurfiati, S.Sos. & 51 \\
\hline 3 & Syamsuri & 52 \\
\hline 4 & Ratna Hapsari Aningdyah & 39 \\
\hline 5 & Nurhidayati & 28,5 \\
\hline 6 & Yayak Muflihana Hanik & 24 \\
\hline 7 & Esti Puji Rahayu & 37 \\
\hline 8 & R. Wegig Wahana & 39 \\
\hline 9 & Sugeng & 39 \\
\hline 10 & Endah Tri Wahjuni, S.Sos. & 59 \\
\hline 11 & Didik Karmahendra & 37 \\
\hline 12 & Kasmuri & 33 \\
\hline 13 & Slamet & 24 \\
\hline 14 & Muhammad Mabror, A. Md. & 50,5 \\
\hline 15 & Ratna Handayani & 39 \\
\hline 16 & Agung Witjaksono & 52 \\
\hline 17 & Gamal Arfan Afandie & 25 \\
\hline 18 & Nanik Wuryaningsih & 27 \\
\hline 19 & Denny Dwi Indiarto & 20,5 \\
\hline 20 & Sulistyarini & 33 \\
\hline 21 & Sri Astati Murhani & 24 \\
\hline 22 & Slamet & 25 \\
\hline 23 & Imam Safi'i & 12 \\
\hline 24 & Suryono & 28 \\
\hline 25 & Soegijo & 40 \\
\hline 26 & Waidi, S.Sos. & 37 \\
\hline 27 & Tutik Herlinawati & 32 \\
\hline 28 & Agus Setiyana & 30,5 \\
\hline 29 & Maskhuroh & 38 \\
\hline 30 & Martono & 28,5 \\
\hline 31 & Didik Srihardi & 45 \\
\hline 32 & Harsumi & 46 \\
\hline 33 & Bambang Basuki W. & 33 \\
\hline 34 & Gunawan & 28 \\
\hline 35 & Esthi Purwanti B.L. & 25 \\
\hline 36 & Titik Suwartini & 49 \\
\hline 37 & Sri Yulistiyo & 22 \\
\hline 38 & Deddy Purnomo & 19 \\
\hline 39 & Sunarto & 28 \\
\hline \multirow[t]{2}{*}{40} & Wahyu Muji L.B. & 39 \\
\hline & TOTAL & 1413,5 \\
\hline
\end{tabular}

Sumber : data diolah dari laporan keuangan tahun anggaran 2013

Berdasarkan tabel 4.3 di atas, untuk mengetahui penjualan CV. Pandan Wangi dianalisis menggunakan statistik deskriptif dengan alat bantu program SPSS for windows 17.0. sebagai berikut: 
Tabel 4.4 Statistik Deskripsi Penjualan Pupuk

\begin{tabular}{|l|l|r|}
\hline \multirow{N}{*}{ Mean } & Valid & 40 \\
\cline { 2 - 3 } & Missing & 0 \\
\hline Median & 35.28 \\
\hline Mode & 33.00 \\
\hline Minimum & 28 \\
\hline Maximum & 12 \\
\hline Sum & 75 \\
\hline
\end{tabular}

Sumber : Data penjualan CV. Pandan Wangi, SPSS V.17

Berdasarkan tabel 4.4. tersebut di atas dapat dideskripsikan bahwa variabel penjualan dengan jumlah data $(\mathrm{N})$ sebanyak 40 memiliki deskripsi data sebagai berikut: (a) Nilai total skor sebesar 1413,5; (b) Nilai mean sebesar 35,28; (c) Nilai median sebesar 33; (d) Nilai modus sebesar 28; (e) Nilai minimum sebesar 12; (f) Nilai maksimum sebesar 75 .

\section{Hasil Pengujian Hipotesis}

Untuk mengetahui atau tidaknya pengaruh tingkat pendidikan karyawan terhadap penjualan pupuk sebagai berikut:

Tabel 4.5. Tabel Kerja Untuk Menghitung Koefisien Regresi

\begin{tabular}{|c|c|c|c|c|c|}
\hline No. & $\begin{array}{c}\text { Pendidikan } \\
(\mathbf{X})\end{array}$ & $\begin{array}{c}\text { Penjualan (ton) } \\
(\mathbf{Y})\end{array}$ & $\mathbf{X}_{\mathbf{2}}$ & $\mathbf{Y}_{\mathbf{2}}$ & $\mathbf{X Y}$ \\
\hline 1 & 5 & 75 & 25 & 5625 & 375 \\
\hline 2 & 5 & 51 & 25 & 2601 & 255 \\
\hline 3 & 5 & 52 & 25 & 2704 & 260 \\
\hline 4 & 3 & 39 & 9 & 1521 & 117 \\
\hline 5 & 3 & 28.5 & 9 & 812.25 & 85.5 \\
\hline 6 & 3 & 24 & 9 & 576 & 72 \\
\hline 7 & 3 & 37 & 9 & 1369 & 111 \\
\hline 8 & 3 & 39 & 9 & 1521 & 117 \\
\hline 9 & 3 & 39 & 9 & 1521 & 117 \\
\hline 10 & 5 & 59 & 25 & 3481 & 295 \\
\hline 11 & 3 & 37 & 9 & 1369 & 111 \\
\hline 12 & 3 & 33 & 9 & 1089 & 99 \\
\hline 13 & 3 & 24 & 9 & 576 & 72 \\
\hline 14 & 4 & 50.5 & 16 & 2550.25 & 202 \\
\hline 15 & 3 & 39 & 9 & 1521 & 117 \\
\hline 16 & 5 & 52 & 25 & 2704 & 260 \\
\hline 17 & 3 & 25 & 9 & 625 & 75 \\
\hline 18 & 3 & 27 & 9 & 729 & 81 \\
\hline 19 & 3 & 20.5 & 9 & 420.25 & 61.5 \\
\hline 20 & 3 & 33 & 9 & 1089 & 99 \\
\hline 21 & 3 & 24 & 9 & 576 & 72 \\
\hline 22 & 3 & 25 & 9 & 625 & 75 \\
\hline 23 & 3 & 12 & 9 & 144 & 36 \\
\hline 24 & 3 & 28 & 9 & 784 & 84 \\
\hline & & & & & \\
\hline
\end{tabular}

\begin{tabular}{|c|c|c|c|c|c|}
\hline No. & $\begin{array}{c}\text { Pendidikan } \\
(\mathbf{X})\end{array}$ & $\begin{array}{c}\text { Penjualan (ton) } \\
(\mathbf{Y})\end{array}$ & $\mathbf{X}_{\mathbf{2}}$ & $\mathbf{Y}_{\mathbf{2}}$ & $\mathbf{X Y}$ \\
\hline 25 & 3 & 40 & 9 & 1600 & 120 \\
\hline 26 & 3 & 37 & 9 & 1369 & 111 \\
\hline 27 & 3 & 32 & 9 & 1024 & 96 \\
\hline 28 & 3 & 30.5 & 9 & 930.25 & 91.5 \\
\hline 29 & 3 & 38 & 9 & 1444 & 114 \\
\hline 30 & 3 & 28.5 & 9 & 812.25 & 85.5 \\
\hline 31 & 3 & 45 & 9 & 2025 & 135 \\
\hline 32 & 3 & 46 & 9 & 2116 & 138 \\
\hline 33 & 3 & 33 & 9 & 1089 & 99 \\
\hline 34 & 3 & 28 & 9 & 784 & 84 \\
\hline 35 & 3 & 25 & 9 & 625 & 75 \\
\hline 36 & 3 & 49 & 9 & 2401 & 147 \\
\hline 37 & 3 & 22 & 9 & 484 & 66 \\
\hline 38 & 3 & 19 & 9 & 361 & 57 \\
\hline 39 & 3 & 28 & 9 & 784 & 84 \\
\hline 40 & 3 & 39 & 9 & 1521 & 117 \\
\hline Jumlah & 131 & 1413.5 & 447 & 55902.25 & 4869 \\
\hline
\end{tabular}

Sumber : data diolah dari laporan keuangan tahun anggaran 2013

Untuk menguji hipotesis berdasarkan tabel 4.5. tersebut dengan analisis regresi linear sederhana. Dalam uji regresi linear sederhana untuk uji hipotesis menggunakan alat bantu SPSS for windows 17.0 yang hasilnya sebagai berikut:

\section{Uji Regresi Linier Sederhana}

Penelitian ini menggunakan regresi linier sederhana dimaksudkan untuk mengetahui pengaruh antara tingkat pendidikan karyawan (X) terhadap penjualan pupuk (Y) dalam bentuk persamaan regresi. Rumus dari bentuk persamaan regresi linier sederhana adalah sebagai berikut.

Tabel 4.6 Uji Linearitas Variabel Tingkat Pendidikan Terhadap Penjualan

\begin{tabular}{ll|r|r|r|r|r|}
\hline Model & Sum of Squares & Df & Mean Square & F & Sig. \\
\hline 1 & Regression & 3203.783 & 1 & 3203.783 & 43.980 & $.000^{\mathrm{a}}$ \\
& Residual & 2768.192 & 38 & 72.847 & & \\
Total & 5971.975 & 39 & & & \\
\hline
\end{tabular}
a. Predictors: (Constant), Pendidikan
b. Dependent Variable: Penjualan

Sumber : Data penjualan CV. Pandan Wangi, SPSS V.17

Berdasarkan tabel 4.6 tersebut dapat dikatakan bahwa dalam uji lineritas, nilai $\mathrm{F}_{\text {hitung }}$ pada Df1 1 dan Df2 10 adalah 43,980, sedangkan $\mathrm{F}_{\text {tabel }}$ adalah 4,08, di lain pihak $\operatorname{sig}_{\text {hit }}<\operatorname{sig}_{\text {pro }}(0,000<0,05)$, hal ini dapat dikatakan bahwa tingkat pendidikan 
karyawan terhadap penjualan pupuk $\mathrm{CV}$. Pandan Wangi mempunyai hubungan yang linier.

\section{Uji Korelasi}

Uji korelasi digunakan untuk mencari keeratan hubungan antara tingkat pendidikan karyawan dengan penjualan pupuk.

Hipotesis dalam uji korelasi adalah sebagai berikut:

a. $\mathrm{H}_{0}$ ditolak apabila nilai $\mathrm{Sig}_{\text {hit }} \leq \operatorname{Sig}_{\text {prob }}$ atau $r_{\text {hitung }} \geq r_{\text {tabel }}$, ada hubungan tingkat pendidikan karyawan dengan penjualan pupuk pada CV. Pandan Wangi.

b. $\mathrm{H}_{0}$ diterima apabila nilai $\mathrm{Sig}_{\text {hit }}>\mathrm{Sig}_{\text {prob }}$ atau $r_{\text {hitung }}<r_{\text {tabel }}$, tidak ada hubungan tingkat pendidikan karyawan dengan penjualan pupuk pada CV. Pandan Wangi.

Atas dasar tabel $4.6 \mathrm{di}$ atas hasil untuk uji korelasi antara tingkat pendidikan karyawan dengan penjualan pupuk, yang diolah dengan SPSS V.17 sebagai berikut:

\section{Tabel 4.7 Uji Korelasi}

\begin{tabular}{|l|l|l|l|l|}
\hline Model & $\mathrm{R}$ & $\mathrm{R}$ Square & $\begin{array}{l}\text { Adjusted R } \\
\text { Square }\end{array}$ & $\begin{array}{l}\text { Std. Error of the } \\
\text { Estimate }\end{array}$ \\
\hline 1 & .732 & .536 & .524 & 8.535 \\
\hline
\end{tabular}

Sumber : Data penjualan CV. Pandan Wangi, SPSS V.17

Berdasarkan tabel 4.7 tersebut dapat dikatakan bahwa $r_{\text {hitung }}$ sebesar 0,732 sedangkan $r_{\text {tabel }} 0,312$. Di lain pihak nilai $\mathrm{Sig}_{\text {hit }}$ sebesar 0,000 dan $\mathrm{Sig}_{\text {prob }}$ sebesar 0,05. Hal ini berarti nilai $r_{\text {hitung }} \geq r_{\text {tabel }}(0,733 \geq$ $0,312)$ atau $\operatorname{Sig}_{\text {hit }} \leq \operatorname{Sig}_{\text {prob }}(0,000 \leq 0,05)$. Dapat diartikan bahwa ada hubungan antara tingkat pendidikan karyawan dengan penjualan pupuk pada CV. Pandan Wangi.

Dengan demikian diperoleh pula nilai untuk $R^{2}$. Nilai $R^{2}$ adalah sebesar $53,73 \%$. Hal ini dapat diartikan bahwa sebesar 53,73\% variabel penjualan pupuk dipengaruhi oleh tingkat pendidikan karyawan sedangkan sisanya $46,27 \%$ dipengaruhi oleh faktor yang tidak diteliti dalam penelitian ini.

3. Uji F/Uji Fisher/Uji Keseluruhan

Uji Fisher digunakan untuk mencari pengaruh tingkat pendidikan karyawan terhadap penjualan pupuk.

Hipotesis uji Fisher yang digunakan adalah sebagai berikut:

a. $\mathrm{H}_{0}$ ditolak bila nilai $\mathrm{F}_{\text {hitung }} \geq \mathrm{F}_{\text {tabel }}$ atau $\mathrm{Sig}_{\text {hit }} \leq$ Sig $_{\text {prob }}$ berarti ada pengaruh tingkat pendidikan terhadap penjualan pada perusahaan CV. Pandan Wangi.

b. $\mathrm{H}_{0}$ diterima bila nilai $\mathrm{F}_{\text {hitung }}<\mathrm{F}_{\text {tabel }}$ atau $\mathrm{Sig}_{\text {hit }}>\mathrm{Sig}_{\text {prob }}$ berarti tidak ada pengaruh tingkat pendidikan karyawan terhadap penjualan pupuk pada CV. Pandan Wangi.

Berdasarkan penjelasan di atas diperoleh hasil perhitungan dalam uji Fisher dapat dilihat pada tabel 4.8 sebagai berikut:

\section{Tabel 4.8 Uji Fisher}

\begin{tabular}{|c|c|c|c|c|c|c|}
\hline \multicolumn{7}{|c|}{ ANOVA $^{b}$} \\
\hline & Model & $\begin{array}{l}\text { Sum of } \\
\text { Squares }\end{array}$ & Df & Mean Square & $\mathrm{F}$ & Sig. \\
\hline \multirow[t]{2}{*}{1} & $\begin{array}{l}\text { Regression } \\
\text { Residual }\end{array}$ & $\begin{array}{l}3203.783 \\
2768.192\end{array}$ & $\begin{array}{r}1 \\
38\end{array}$ & \begin{tabular}{|r|}
203.783 \\
72.847
\end{tabular} & 43.980 & $.000^{\mathrm{a}}$ \\
\hline & Total & 5971.975 & 39 & & & \\
\hline
\end{tabular}

b. Dependent Variable: Penjualan

Sumber : Data penjualan CV. Pandan Wangi, SPSS V. 17

Atas dasar tabel 4.8 dapat diketahui nilai $\mathrm{F}_{\text {hitung }}$ sebesar 43,980 sedangkan nilai $\mathrm{F}_{\text {tabel }}$ sebesar 4,08. Di lain pihak nilai $\mathrm{Sig}_{\text {hit }}$ sebesar 0,000 dan $\mathrm{Sig}_{\text {prob }}$ sebesar 0,05. Hal ini berarti bahwa nilai $F_{\text {hitung }} \geq F_{\text {tabel }}(43,980$ $\geq 4,08) \operatorname{Sig}_{\text {hit }} \leq \operatorname{Sig}_{\text {prob }}(0,000 \leq 0,05)$. Hal ini dapat dikatakan bahwa $\mathrm{H}_{0}$ ditolak, artinya ada pengaruh antara tingkat pendidikan karyawan terhadap penjualan pupuk pada CV. Pandan Wangi.

Selain untuk mencari pengaruh uji $\mathrm{F}$ atau Anova ini digunakan untuk uji 
linearitas. Karena $\mathrm{F}_{\text {hitung }}$ sebesar $43,980 \geq$ $\mathrm{F}_{\text {tabel }}$ sebesar 4,08 yang artinya ada hubungan yang linear antar dua variabel tingkat pendidikan karyawan dan penjualan pupuk.

4. Uji Koefisien Regresi (Ujit)

Uji t digunakan untuk mengetahui beda pengaruh antara tingkat pendidikan karyawan terhadap penjualan pupuk.

Hipotesis yang digunakan dalam Uji t adalah sebagai berikut:

a. $\mathrm{H}_{0}$ ditolak bila nilai $\mathrm{t}_{\text {hitung }} \geq \mathrm{t}_{\text {tabel }}$ atau Sig $\operatorname{Sit}_{\text {hit }}$ $\leq$ Sig $_{\text {prob }}$ berarti ada beda pengaruh tingkat pendidikan karyawan terhadap penjualan pupuk pada CV. Pandan Wangi.

b. $\mathrm{H}_{0}$ diterima bila nilai $\mathrm{t}_{\text {hitung }}<\mathrm{t}_{\text {tabel }}$ atau $\mathrm{Sig}_{\text {hit }}>\mathrm{Sig}_{\text {prob }}$ berarti tidak ada beda pengaruh tingkat pendidikan karyawan terhadap penjualan pupuk pada $\mathrm{CV}$. Pandan Wangi.

Atas dasar tabel kerja 4.8 di atas yang diperoleh hasil uji t dapat dilihat pada tabel 4.9 sebagai berikut:

\section{Tabel 4.9 Uji t}

\begin{tabular}{|c|r|r|r|r|r|r|}
\hline \multicolumn{2}{|c|}{ Model } & \multicolumn{1}{|c|}{ Unstandardized Coefficients } & $\begin{array}{c}\text { Standardized } \\
\text { Coefficients }\end{array}$ & \multirow{2}{*}{ T } & \multirow{2}{*}{ Sig. } \\
\cline { 3 - 5 } & B & Std. Error & Beta & & \\
\hline 1 & (Constant) & 8.448 & 6.730 & & 1.255 & .217 \\
\cline { 2 - 4 } & Pendidikan & 13.350 & 2.013 & .732 & 6.632 & .000 \\
\hline
\end{tabular}
a. Dependent Variable: Penjualan

Sumber : Data penjualan CV. Pandan Wangi, SPSS V.17

Dari hasil di atas dalam koefisien regresi atau uji $\mathrm{t}$ diperoleh nilai $\mathrm{t}_{\text {hitung }}$ sebesar 6,632 $\geq \mathrm{t}_{\text {tabel }}$ sebesar 1,745. Dari hasil uji t tersebut dapat dikatakan bahwa $\mathrm{H}_{0}$ ditolak artinya terdapat beda pengaruh antara tingkat pendidikan karyawan terhadap penjualan pupuk pada CV. Pandan Wangi.

\section{Simpulan Hasil Analisis}

Dari hasil analisis data yang dilakukan dalam penelitian ini diambil simpulan sebagai berikut: a. Simpulan Uji Korelasi

Dalam uji korelasi diperoleh nilai $r_{\text {hitung }}$ sebesar 0,732 sedangkan nilai $r_{\text {tabel }}$ sebesar 0,312. Di lain pihak nilai $\mathrm{Sig}_{\text {hit }}$ sebesar 0,000 dan nilai $\operatorname{Sig}_{\text {prob }}$ sebesar 0,05. Hal ini berarti bahwa $r_{\text {hitung }} \geq r_{\text {tabel }}(0,732 \geq 0,312)$ atau $\operatorname{Sig}_{\text {hit }} \leq \operatorname{Sig}_{\text {prob }}(0,000 \leq 0,05)$. Diketahui pula nilai $\mathrm{R}^{2}$ sebesar $53,73 \%$, dapat dikatakan bahwa sebesar 53,73\% variabel terikat (Y) dalam penelitian ini penjualan pupuk dipengaruhi oleh tingkat pendidikan karyawan sebagai variabel bebas (X), sisanya 46,28\% dipengaruhi faktor lain.

Dapat disimpulkan $\mathrm{H}_{0}$ ditolak artinya ada hubungan antara tingkat pendidikan karyawan dengan penjualan pupuk pada CV. Pandan Wangi dengan demikian berarti terjadi penolakan untuk $\mathrm{H}_{0}$ dapat digambarkan pada gambar 4.1. sebagai berikut:

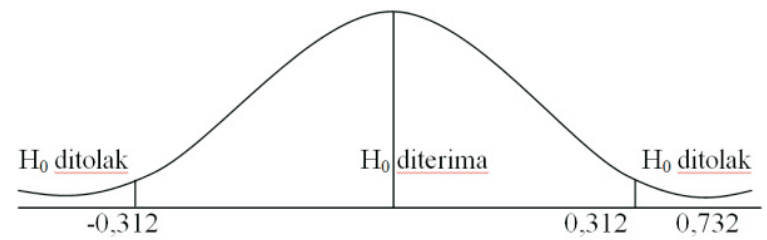

\section{Gambar 4.1 Daerah Penerimaan dan} Penolakan $\mathrm{H}_{0}$ pada Korelasi

b. Simpulan Uji Fisher

Dari hasil analisis data untuk uji Fisher dalam penelitian ini dapat diperoleh hasil nilai $\mathrm{F}_{\text {hitung }}$ sebesar 43,980 sedangkan $\mathrm{F}_{\text {tabel }}$ sebesar 4,08. Di lain pihak $\mathrm{Sig}_{\text {hit }}$ sebesar 0,000 dan $\operatorname{Sig}_{\text {prob }}$ sebesar 0,05. Hal ini berarti bahwa $\mathrm{F}_{\text {hitung }} \geq \mathrm{F}_{\text {tabel }}(43,980 \geq 4,08)$ atau $\operatorname{Sig}_{\text {hit }} \leq \operatorname{Sig}_{\text {prob }}(0,000 \leq 0,05)$.

Dengan demikian dapat disimpulkan bahwa $\mathrm{H}_{0}$ ditolak, artinya tingkat pendidikan karyawan memiliki pengaruh terhadap penjualan pupuk pada CV. Pandan Wangi.

Berarti dapat digambarkan daerah penolakan $\mathrm{H}_{0}$ pada uji Fisher dapat dilihat pada gambar 4.2. berikut: 


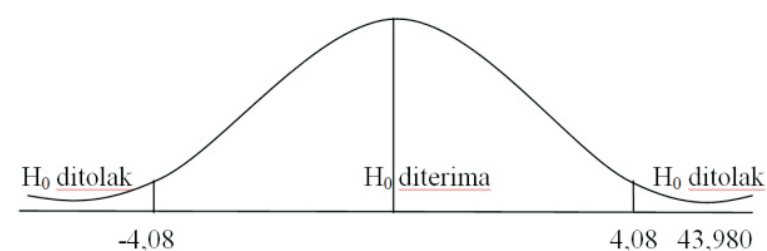

Gambar 4.2 Daerah Penerimaan dan Penolakan $\mathrm{H}_{0}$ pada Uji $\mathrm{F}$

c. Simpulan Koefisien Regresi (Ujit)

Dari hasil analisis koefisien regresi atau uji

$\mathrm{t}$ diperoleh nilai $\mathrm{t}_{\text {hitung }}$ sebesar 6,632

sedangkan nilai $\mathrm{t}_{\text {tabel }}$ sebesar 2,024. Di lain pihak nilai $\mathrm{Sig}_{\text {hit }}$ sebesar 0,000 dan nilai $\mathrm{Sig}_{\text {prob }}$ sebesar 0,05. Hal ini berarti bahwa nilai $\mathrm{t}_{\text {hitung }} \geq \mathrm{t}_{\text {tabel }}(6,632 \geq 2,024)$ atau $\operatorname{Sig}_{\text {hit }} \leq$ $\operatorname{Sig}_{\text {prob }}(0,000 \leq 0,05)$. Disimpulkan bahwa $\mathrm{H}_{0}$ ditolak, artinya tingkat pendidikan karyawan memiliki beda pengaruh terhadap penjualan pupuk pada CV. Pandan Wangi.

Lebih lanjut apabila dilihat dalam persamaan regresi diperoleh persamaan nilai $Y=8.448+13.350$. Dengan demikian dapat disimpulkan dari persamaan tersebut adalah tingkat pendidikan karyawan meningkat sebesar $1 \%$, penjualan pupuk akan naik sebesar 21,798, dengan faktor lain dianggap tetap.

Dapat digambarkan daerah penolakan $\mathrm{H}_{0}$ pada uji t dalam penelitian ini dapat dilihat pada gambar 4.3 sebagai berikut:

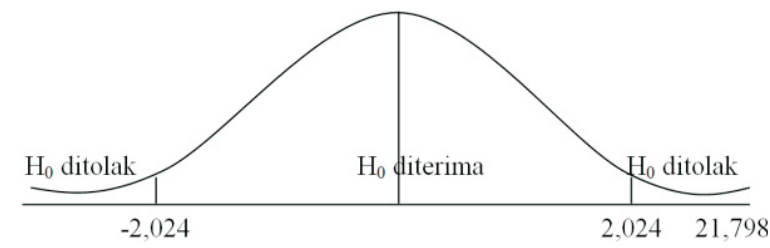

Gambar 4.3 Daerah Penerimaan dan Penolakan $\mathrm{H}_{0}$ pada Uji t

\section{PEMBAHASAN}

Hasil dari penelitian ini menyatakan bahwa tingkat pendidikan karyawan mempunyai pengaruh terhadap penjualan pupuk. Yang artinya tingkat pendidikan karyawan yang baik untuk mematuhi peraturan sehingga dapat meningkatkan penjualan pupuk. Karena produktivitas merupakan jumlah yang dihasilkan dan jumlah setiap sumber yang dipergunakan selama produksi berlangsung.

Pembahasan untuk penelitian ini menggunakan uji regresi (uji korelasi, uji Fisher, dan uji t) pembahasan untuk uji tersebut adalah sebagi berikut:

1. Pembahasan Uji Korelasi

Untuk uji korelasi diperoleh nilai $r_{\text {hitung }}$ sebesar 0,732 sedangkan nilai $r_{\text {tabel }}$ sebesar 0,312. Di lain pihak $\operatorname{Sig}_{\text {hit }}$ sebesar 0,000 dan nilai $\operatorname{Sig}_{\text {prob }}$ sebesar 0,05. Hal ini berarti bahwa nilai $r_{\text {hitung }} \geq r_{\text {tabel }}(0,732 \geq 0312)$ atau $\operatorname{Sig}_{\text {hit }} \leq \operatorname{Sig}_{\text {prob }}(0,000 \leq 0,05)$. Selain itu, dalam peneltian ini diperoleh nilai $\mathrm{R}^{2}$ sebesar 53,73. Hal ini menunjukkan bahwa sebanyak 53,73\% tingkat pendidikan karyawan dipengaruhi oleh penjualan karyawan. Dengan hal ini $\mathrm{H}_{0}$ ditolak, artinya ada hubungan tingkat pendidikan karyawan dengan penjualan pupuk pada CV. Pandan Wangi.

Hal ini sesuai dengan pendapat Yeni Nuraeni dalam jurnal yang berjudul Pengaruh Biaya Sales Promotion Terhadap Peningkatan Volume Penjualan Produk PT. Sinar Inesco Sambawa Taraju (2013: 1). Dari hasil uji kolerasi diketahui besarnya nilai kolerasi (r) 0,87 yang berarti tingkat pendidikan yang dibutuhkan oleh PT. Sinar Inesco Sambawa Taraju Tasikmalaya mempunyai hubungan yang sangat positif dengan peningkatan penjualan produk dan termasuk kategori kuat.

2. Pembahasan Uji Fisher

Untuk uji Fisher diperoleh nilai $F_{\text {hitung }}$ sebesar 43,980 sedangkan nilai $F_{\text {tabel }}$ sebesar 4,098. Di lain pihak nilai Sig $_{\text {hit }}$ sebesar 0,000 dan nilai Sig $_{\text {prob }}$ sebesar 0,05. Hal ini berarti nilai $F_{\text {hitung }} \geq F_{\text {tabel }}(43,980 \geq$ $4,098)$ atau $\operatorname{Sig}_{\text {hit }} \leq \operatorname{Sig}_{\text {prob }}(0,000 \leq 0,05)$. Dengan hal ini berarti $\mathrm{H}_{0}$ ditolak, artinya ada pengaruh tingkat pendidikan karyawan terhadap penjualan pupuk pada CV.Pandan Wangi. 
Dari penelitian terdahulu Lilin Puji Handayani dalam Jurnal yang berjudul Analisis Faktor-Faktor Yang Mempengaruhi Penjualan pada Industri Kecil Genteng di Kecamatan Jaten Kabupaten Karanganyar (2012:1) nilai uji-F juga menunjukkan bahwa variabel usia, jenjang pendidikan, pengalaman usaha, upah karyawan dan jumlah karyawan yang bekerja pada pengusaha secara bersamasama mempunyai pengaruh secara signifikan penjualan pada industri kecil genteng.

Menurut Siswanto Sastro Hadiwiryo (2005:200) "Jenis pendidikan dan pelatihan yang disesuaikan dengan perusahaan khusus tergantung kepada beberapa faktor, seperti kecakapan yang diperlukan dalam jabatan/pekerjan yang harus diisi dan masalah yang diharapkan dapat diperoleh jalan pemecahannya pada perusahaan."

Tingkat pendidikan merupakan sebuah skala atau ukuran dari adanya kompetensi yang dimiliki oleh perserta didik. Peserta didik sendiri dalam proses pembelajaran agar dapat melanjutkan pada tingkat pendidikan selanjutnya memiliki beberapa faktor yaitu: usia, pekerjaan, status ekonomi, sosial budaya, lingkungan.

3. Pembahasan Ujit

Dari hasil analisis koefisien regresi atau uji $\mathrm{t}$ diperoleh nilai $\mathrm{t}_{\text {hitung }}$ sebesar 6,632 sedangkan nilai $\mathrm{t}_{\text {tabel }}$ sebesar 2,024. Di lain pihak nilai Sig $_{\text {hit }}$ sebesar 0,000 dan nilai $\mathrm{Sig}_{\text {prob }}$ sebesar 0,05 . Hal ini berarti bahwa nilai $t_{\text {hitung }} \geq t_{\text {tabel }}(6,632 \geq 2,024)$ atau $\operatorname{Sig}_{\text {hit }} \leq$ $\operatorname{Sig}_{\text {prob }}(0,000 \leq 0,05)$. Disimpulkan bahwa $\mathrm{H}_{0}$ ditolak, artinya tingkat pendidikan karyawan memiliki beda pengaruh terhadap penjualan pupuk pada CV. Pandan Wangi.

Lebih lanjut apabila dilihat dalam persamaan regresi diperoleh persamaan nilai $Y=8.448+13.350$. Dengan demikian dapat disimpulkan dari persamaan tersebut adalah tingkat pendidikan karyawan meningkat sebesar $1 \%$, penjualan pupuk akan naik sebesar 21,798, dengan faktor lain dianggap tetap.

Hal ini sesuai dengan penelitian terdahulu dari Yeni Nuraeni dalam jurnal yang berjudul Pengaruh Biaya Sales Promotion Terhadap Peningkatan Penjualan Produk PT. Sinar Inesco Sambawa Taraju (2013: 1) Pada uji hipotesa yang penulis lakukan diperoleh nilai $\mathrm{T}_{\text {hitung }}$ sebesar 6,198 dan nilai $\mathrm{T}_{\text {tabel }}$ pada $\alpha=0,05$ dan dk $\mathrm{n} 2$ adalah 2, 353; sehingga $t_{\text {hitung }}=t_{\text {tabel }}$ : yang artinya $\mathrm{H}_{0}$ ditolak dan Ha diterima. Dengan demikian dapat disimpulkan bahwa pendidikan berpengaruh secara signifikan terhadap peningkatan penjualan produk pada perusahaan PT. Sinar Inesco, Sambawa Taraju Kab. Tasikmalaya.

\section{PENUTUP}

\section{Simpulan}

Simpulan dari penelitian mengenai Pengaruh Tingkat Pendidikan Karyawan terhadap Penjualan Pupuk CV. Pandan Wangi adalah sebagai berikut:

1. Tingkat Pendidikan Karyawan yang ada ada di CV. Pandan Wangi yang memiliki jumlah terbanyak adalah SMA sebesar 34 orang, tingkat pendidikan D3 1 orang, tingkat pendidikan S1 berjumlah 5 orang.

2. Penjualan pupuk CV. Pandan Wangi pada tahun 2013, setelah diolah dengan statistik diskriptif diperoleh hasil sebagai berikut: (a) Nilai total skor sebesar 1413,5; (b) Nilai mean sebesar 35.28; (c) Nilai median sebesar 33.00; (d) Nilai modus sebesar 28; (e) Nilai minimum sebesar 12; (g) Nilai maksimum sebesar 75. Dari analisis diskriptif di atas maka penjualan pupuk CV. Pandan Wangi, mempunyai nilai yang baik.

3. Tingkat pendidikan karyawan berpengaruh positif dan signifikan terhadap penjualan CV. Pandan Wangi, sehingga adanya peningkatan pendidikan karyawan akan meningkatkan penjualan pupuk. 
Berdasarkan pada koefisien regresi tingkat pendidikan karyawan bernilai positif sebesar 13.350. Hal ini menunjukkan bahwa tingkat pendidikan karyawan berpengaruh terhadap penjualan pupuk CV.Pandan Wangi.

Terbukti dari hasil analisis regresi yang memuat uji korelasi, uji F, dan uji t.

Dari uji korelasi dapat diketahui bahwa bahwa $r_{\text {hitung }}$ sebesar 0,732 sedangkan $r_{\text {tabel }}$ 0,312. Di lain pihak nilai $\mathrm{Sig}_{\text {hit }}$ sebesar 0,000 dan $\mathrm{Sig}_{\text {prob }}$ sebesar 0,05 . Hal ini berarti nilai $r_{\text {hitung }} \geq \mathrm{r}_{\text {tabel }}(0,733 \geq 0,312)$ atau $\operatorname{Sig}_{\text {hit }} \leq \operatorname{Sig}_{\text {prob }}$ $(0,000 \leq 0,05)$. Dapat diartikan bahwa ada hubungan antara tingkat pendidikan karyawan dengan penjualan pupuk pada $\mathrm{CV}$. Pandan Wangi.

Dengan demikian diperoleh pula nilai untuk $\mathrm{R}^{2}$. Nilai $\mathrm{R}^{2}$ sebesar $53,73 \%$. Hal ini dapat diartikan bahwa sebesar 53,73\% variabel penjualan pupuk dipengaruhi oleh tingkat pendidikan karyawan sedangkan sisanya $46,27 \%$ dipengaruhi oleh faktor yang tidak diteliti dalam penelitian ini.

Sedangkan diketahui nilai $\mathrm{F}_{\text {hitung }}$ sebesar 43,980 sedangkan nilai $\mathrm{Ft}_{\text {abel }}$ sebesar 4,08. Di lain pihak nilai $\mathrm{Sig}_{\text {hit }}$ sebesar 0,000 dan $\mathrm{Sig}_{\text {prob }}$ sebesar 0,05 . Hal ini berarti bahwa nilai $\mathrm{F}_{\text {hitung }}$ $\geq F_{\text {tabel }}(43,980 \geq 4,08)$ dan $\operatorname{Sig}_{\text {hit }} \leq \operatorname{Sig}_{\text {prob }}(0,000$ $\leq 0,05)$, maka $\mathrm{H}_{0}$ ditolak, artinya ada pengaruh antara tingkat pendidikan karyawan terhadap penjualan pupuk pada CV. Pandan Wangi.

Selain untuk mencari pengaruh uji $\mathrm{F}$ atau Anova ini digunakan untuk uji linearitas. Karena $\mathrm{F}_{\text {hitung }}$ sebesar $43,980 \geq \mathrm{F}_{\text {tabel }}$ sebesar 4,08 yang artinya ada hubungan yang linear antara dua variabel tingkat pendidikan karyawan dan penjualan pupuk.

Selanjutnya dari hasil di atas dalam koefisien regresi atau uji $t$ diperoleh nilai $t_{\text {hitung }}$ sebesar 6,632 $\geq t_{\text {tabel }}$ sebesar 1,745. Dari hasil uji $\mathrm{t}$ tersebut dapat dikatakan bahwa $\mathrm{H}_{0}$ ditolak artinya terdapat beda pengaruh antara tingkat pendidikan karyawan terhadap penjualan pupuk pada CV. Pandan Wangi.
Dari semua uji di atas dapat diambil simpulan bahwa $\mathrm{H}_{0}$ ditolak, artinya bahwa ada pengaruh tingkat pendidikan karyawan terhadap penjualan pupuk pada CV. Pandan Wangi di Desa Pulerejo RT/RW: 12/02 Kecamatan Pilangkenceng, Kabupaten Madiun tahun 2013.

\section{Saran}

Saran yang bisa disampaikan dari hasil penelitian yang didapat adalah:

1. Bagi Perusahaan

Tingkat pendidikan karyawan besar pengaruhnya terhadap penjualan, oleh karena itu pemimpin harus dapat meningkatkan tingkat pendidikan karyawan dengan cara merekrut karyawan yang berpendidikan tinggi.

2. Bagi Karyawan

Bagi karyawan hendaknya menyadari bahwa dalam setiap pembagian kerja menurut tingkat pendidikan sangat diperlukan untuk menjaga mutu perusahaan dalam proses penjualan. Semakin tinggi tingkat pendidikan karyawan maka hasil kerja yang diperoleh akan semakin meningkat. Jadi hendaknya karyawan bisa menempuh pendidikan yang lebih tinggi lagi agar mencapai hasil yang memuaskan dalam menjalankan pekerjaannya.

3. Bagi Penelitian Mendatang

Bagi peneliti yang akan datang sebaiknya dapat mengembangkan atau mencari variabel lain, selain kedisiplinan kerja karena masih banyak faktor lain yang harus diteliti yang dapat mempengaruhi penjualan.

\section{DAFTAR PUSTAKA}

Aston, Robert. 2005. How to Sell: Cara Cepat Menjual. Jakarta: Erlangga.

Bambang Prishardoyo, et al. 2005. Pelajaran Ekonomi SMP Kelas I. Jakarta: PT. Grasindo. 
Basu Swastha dan Ibnu Sukotjo. 2002. Pengantar Bisnis Modern. Yogyakarta: Liberty.

Basu Swastha dan Irawan. 2008. Manajemen Pemasaran Modern. Yogyakarta: Liberty.

Basu Swastha. 2009. Manajemen Penjualan. Yogyakarta: BPFE.

Gabriel Amin Silalahi. 2003. Metodologi Penelitian dan Studi Kasus. Sidoarjo: Citra Media.

Himayati. 2008. Eksplorasi Zahir Accounting. Jakarta: PT. Elek Media Komputindo.

http://fourseasonnews.blogspot.com/2012/0 $5 /$ faktor-yang-mempengaruhitingkat.html, diunduh.20/04/2013.

Husein Umar, 2011. Metode Penelitian untuk Skripsi dan Tesis Bisnis. Jakarta: Rajawali Pers.

Iqbal Hasan. 2004. Analisis Data Penelitian dengan Statistik. Jakarta: PT. Bumi Aksara.

Juliansyah Noor. 2011. Metodologi Penelitian: Skripsi, Tesis, Disertasi, dan Karya Ilmiah. Jakarta: Kencana Prenada Media Group.

Moehar Daniel. 2003. Metode Penelitian Sosial Ekonomi. Jakarta: Bumi Aksara.

Nanang Martono. 2010. Metode Penelitian Kuantitatif: Analisis Isi dan Analisis Data Sekunder. Jakarta: PT. Raja Grafindo Persada.
Prijono Tjipto Heridjanto. 2008. Pengembangan Sumber Daya Manusia: di Antara Peluang dan Tantangan. Jakarta: LIPI Press.

Redaksi RAS. 2009. Rahasia Sukses Berbisnis Sampingan Skala Rumahan. Depok: Raih Asa Sukses.

Siswanto Sastro Hardiwiryo. 2005. Manajemen Tenaga Kerja Indonesia: Pendekatan Administrative dan Operasional. Jakarta: PT. Bumi Aksara.

Sugiyono. 2007. Metode Penelitian Kuantitatif, Kualitatif dan $R \& D$. Bandung: Alfabeta.

Sugiyono. 2010. Metode Penelitian Kuantitatif, Kualitatif dan $R \& D$. Bandung: Alfabeta.

Suharsimi Arikunto. 2010. Prosedur Penelitian: Suatu Pendekatan Praktek. Jakarta: Rineka Cipta.

Tim IKIP PGRI Madiun, 2012. Pedoman Penulisan Skripsi. IKIP PGRI Madiun. Madiun.

Undang-Undang No. 13 tahun 2003 tentang Ketenagakerjaan.

UU RI No. 20 Tahun 2003 tentang Sistem Pendidikan Nasional. 